\title{
Microcystic adnexal carcinoma: an immunohistochemical reappraisal
}

\author{
Mai P Hoang ${ }^{1}$, Karen A Dresser ${ }^{1}$, Payal Kapur², Whitney A High ${ }^{3}$ and Meera Mahalingam ${ }^{1}$ \\ ${ }^{1}$ Department of Pathology, UMass Medical School, Worcester, MA, USA; ${ }^{2}$ Department of Pathology, \\ University of Texas Southwestern Medical Center, Dallas, TX, USA and ${ }^{3}$ Department of Dermatology, \\ University of Colorado Health Sciences Center, Aurora, CO, USA
}

\begin{abstract}
Even though immunohistochemical comparisons of microcystic adnexal carcinoma vs infiltrative basal cell carcinoma and desmoplastic trichoepithelioma exist, they are mostly restricted to the use of a single stain. In addition, a comparison with squamous cell carcinoma has not been reported previously. In this study, we compare the expression of cytokeratin (CK) 15, CK7, CK20, CK903, carcinoembryonic antigen (CEA), CD10, CD15 and BerEP4 in 13 microcystic adnexal carcinoma, eight desmoplastic trichoepithelioma, 10 infiltrative basal cell carcinoma, and eight squamous cell carcinoma of which five exhibited ductal differentiation. We found that the majority of microcystic adnexal carcinoma (92\%) and desmoplastic trichoepithelioma (100\%) cases expressed CK15 while the infiltrative basal cell carcinoma and squamous cell carcinoma cases were all negative. Forty percent of infiltrative basal cell carcinoma expressed CK7; while only two microcystic adnexal carcinoma cases $(15 \%)$ and one squamous cell carcinoma with ductal differentiation (12\%) expressed CK7 in the remaining three tumor categories. None of the desmoplastic trichoepithelioma expressed CK7. All tumors were strongly positive for CK903. While the neoplastic cells were negative, luminal staining of ductal structures was noted for CK7, CD15 and CEA in some of the microcystic adnexal carcinoma, desmoplastic trichoepithelioma and squamous cell carcinoma with ductal differentiation cases. Sixty percent of infiltrative basal cell carcinoma, $31 \%$ of microcystic adnexal carcinoma, and $25 \%$ of squamous cell carcinoma express CD10. BerEP4 expression was noted in $38 \%$ of microcystic adnexal carcinoma, $57 \%$ of desmoplastic trichoepithelioma, $100 \%$ of infiltrative basal cell carcinoma, and $38 \%$ of squamous cell carcinoma. In conclusion, we found CK15 to be a useful marker in distinguishing microcystic adnexal carcinoma from infiltrative basal cell carcinoma and squamous cell carcinoma with ductal differentiation. Our experience indicates that microcystic adnexal carcinoma and desmoplastic trichoepithelioma have a similar immunohistochemical profile that is, CK15 + and BerEP4 $+I-$; thus, additional studies are needed to separate these two entities.
\end{abstract}

Modern Pathology (2008) 21, 178-185; doi:10.1038/modpathol.3801000; published online 7 December 2007

Keywords: microcystic adnexal carcinoma; squamous cell carcinoma with ductal differentiation; desmoplastic trichoepithelioma; infiltrative basal cell carcinoma; cytokeratin 15; BerEP4

First reported in 1982 by Goldstein et al, ${ }^{1}$ microcystic adnexal carcinoma has been referred to by a variety of names-all of which allude to the clinical behavior and histopathologic features of this lesion. Briefly, these include sweat gland carcinoma with syringomatous features, malignant syringoma, sclerosing sweat duct carcinoma and syringomatous carcinoma. ${ }^{2-5}$ Clinically, microcystic adnexal carcinoma has a predilection for the head and neck area and is slow growing but locally aggressive ${ }^{6-8}$ From a

Correspondence: Dr MP Hoang, MD, Dermatopathology Unit, Massachusetts General Hospital, 55 Fruit Street, Warren 820, Boston, MA 02114, USA.

E-mail: mhoang@partners.org

Received 23 July 2007; revised and accepted 08 October 2007; published online 7 December 2007 histopathologic perspective, the main differential diagnosis for microcystic adnexal carcinoma, a stratified, infiltrating neoplasm characterized by a superficial component of keratinous cysts and a deeper component of smaller nests and strands of cells embedded in a markedly hyalinized stroma, is sclerosing/infiltrative basal cell carcinoma and desmoplastic trichoepithelioma. In addition, we noticed misdiagnosis of a few cases of microcystic adnexal carcinoma as squamous cell carcinoma at our institution-most likely a consequence of the biopsy technique (superficial shave). The differentiation of microcystic adnexal carcinoma from any of these other entities is not merely semantic but extremely relevant to clinical management. Microcystic adnexal carcinoma has an increased propensity for perineural invasion-a feature that is 
believed to account for its high recurrence rate. While local recurrence is reported in $50 \%$ of cases of microcystic adnexal carcinoma with positive margins, $40-60 \%$ of patients experience one or more local recurrences anywhere from 6 months to 30 years after standard wide local excision., ${ }^{4,6,7,9-11}$ Thus, while the standard of care for microcystic adnexal carcinoma is wide local excision, no further management is mandated for a desmoplastic trichoepithelioma.

Therefore, although the histology of microcystic adnexal carcinoma is fairly distinctive, it appears that immunohistochemical confirmation of the same would be a useful ancillary tool. This is particularly true if the biopsy is a superficial one precluding an appreciation of the characteristic stratified nature of the neoplasm-a defining feature of microcystic adnexal carcinoma. However, studies investigating the utility of immunohistochemistry in the diagnosis of microcystic adnexal carcinoma are few and restricted both in the spectrum of lesions and antibodies studied (Table 1). ${ }^{12-26}$ Thus, even though immunohistochemical comparisons of microcystic adnexal carcinoma vs infiltrative basal cell carcinoma and desmoplastic trichoepithelioma exist in the published literature, they are confined to a single stain; and to date, only two studies employing a panel of immunohistochemical stains are performed. ${ }^{17,19,21,23,24,26}$ In addition, a comparative study of microcystic adnexal carcinoma with squamous cell carcinoma particularly squamous cell carcinoma with ductal differentiation has not, to our knowledge, been reported previously.

We sought to ascertain the utility of immunohistochemistry in differentiating microcystic adnexal carcinoma from its histologic mimics by using a comprehensive immunohistochemical panel that included stains previously and even more recently reported to be diagnostically useful (CK7, CK20, CD15, CEA and BerEP4). In addition, we expanded the panel to incorporate novel stains (CK15, CD10 and CK903). All of the lesions included in the study were characterized by infiltrating strands and islands of cells. They included 13 microcystic adnexal carcinoma, eight desmoplastic trichoepithelioma, eight squamous cell carcinoma of which five exhibited ductal differentiation, and 10 infiltrative basal cell carcinoma.

\section{Materials and methods}

The study was approved by the UMass Medical Center (IRB No H-12484) and University of Texas Southwestern Medical Center (IRB No 062007-076) institutional review boards. Archival materials were retrieved from the pathology files of UMass Medical Center, Worcester, MA, USA. Briefly, these included nine cases of microcystic adnexal carcinoma, eight cases of squamous cell carcinoma, eight cases of desmoplastic trichoepithelioma, and 10 cases of infiltrative basal cell carcinoma (Table 2). Of the squamous cell carcinoma category, we included five cases of squamous cell carcinoma with ductal differentiation. Four additional cases of microcystic adnexal carcinoma were retrieved from the archives of University of Texas Southwestern Medical Center, (Dallas, TX, USA) and University of Colorado Health Sciences Center (Aurora, CO, USA). Histologic sections of all cases were re-reviewed and the diagnoses confirmed independently by two dermatopathologists (MPH and MM). All patient data were de-identified.

Immunohistochemical studies were performed on five-micrometer-thick sections of formalin-fixed, paraffin-embedded tissue. Antigen retrieval was carried out with heat-induced epitope retrieval buffer in an 800-W microwave oven for $15 \mathrm{~min}$ for all stains with the exception of BerEP4; in which digestion with proteinase-K (Dako, Carpinteria, CA, USA) for $5 \mathrm{~min}$ was performed. The slides were stained on the DAKO Autostainer using the EnVision + (Dako) staining reagents and primary antibodies against CD10 (56C6, 1:10, Vector Laboratories, Burlingame, CA, USA), CD15 (MMA, 1:20, BD Biosciences, San Jose, CA, USA), CEA (1:6000, Dako), CK903 (34ßE12 1:50, Dako), CK7 (OV-TL 12/ 30, 1:100, Dako), CK20 ( $K_{\mathrm{s}} 20.81: 200$, Dako), CK15 (LHK15, 1:80, NeoMarkers, Fremont, CA, USA), and BerEP4 (BerEP4, 1:150, Dako). Appropriate positive and negative controls were included.

The immunostains were reviewed by two dermatopathologists (MPH, MM), and disagreements were reviewed together to achieve a consensus score. Positive staining of CK15, CK7, CK20, CK903, CD10, CD15, CEA and BerEP4 was scored as $3+$ (greater than $50 \%$ of the tumor cells), $2+(10-49 \%)$ or $1+/$ negative (less than $10 \%$ ).

\section{Results}

\section{Microcystic Adnexal Carcinoma}

A total of 13 cases with a male/female ratio of 3:7 was studied. Thirteen specimens of microcystic adnexal carcinoma were from 10 patients (age range, 65-93 years; mean, 79 years; median, 80 years). Two patients had recurrent disease. Involved sites included the lower eyelid (one patient), nose (two patients), cheek (two), perioral (one), upper lip (one), chin (one), neck (one) and axilla (one).

Histologic features of all cases were characterized by superficial portion composed of small keratocysts (containing lamellar keratin) with alternating islands and strands of basaloid and epithelioid cells showing variable ductal differentiation and calcification (Figure 1a). The mid portion of the tumor was characterized by strands rather than islands (Figures 1a and 2a) and the deep portion, extending into the subcutaneous tissue and muscle (Figures $1 \mathrm{~b}$ and $2 \mathrm{~b}$ ) by even smaller nests and strands of cells in a 
Table 1 Historic overview of immunohistochemical profile of microcystic adnexal carcinoma to date

\begin{tabular}{|c|c|c|c|c|c|c|c|c|c|c|c|c|c|c|c|c|}
\hline & $1986^{12}$ & $1987^{13}$ & $1987^{14}$ & ${ }_{15}^{1988}$ & $\begin{array}{l}1990 \\
16\end{array}$ & ${ }_{17}^{1990}$ & $1993^{18}$ & $1995^{19}$ & $1995^{20}$ & $2000^{21}$ & $2001^{22}$ & $2001^{23}$ & $2005^{24}$ & $2006^{25}$ & $\underset{26}{2007}$ & $\begin{array}{l}\text { Current } \\
\text { study } \\
2007\end{array}$ \\
\hline Cases studied & 2 & 1 & 2 & 1 & 1 & 12 & 17 & 6 & 8 & 8 & 3 & 10 & 7 & 1 & 13 & 13 \\
\hline $\begin{array}{l}\text { Alpha- } \\
\text { lactalbumin }\end{array}$ & & & $1 / 2$ & & & & & & & & & & & & & \\
\hline $\begin{array}{l}\text { Alpha-smooth } \\
\text { muscle actin }\end{array}$ & & & & & & & & & & & $0 / 3$ & + & & $1 / 1$ & & \\
\hline Bcl-2 & & & & & & & & & & & & $\begin{array}{l}\text { Focal } \\
+\end{array}$ & & & & \\
\hline BerEP4 & & & & & & & & & & & & $+^{a}$ & & & $0 / 13$ & $5 / 13$ \\
\hline $\begin{array}{l}\text { Beta-2 } \\
\text { microglobulin }\end{array}$ & & & $0 / 2$ & & & & & & & & & & & & & \\
\hline $\begin{array}{l}\text { Blood group } \\
\text { isoantigens A, } \\
\mathbf{B}, \mathbf{H}\end{array}$ & & & $1 / 2$ & & & & & & & & & & & & & \\
\hline BRST-2 & & & & & & & & & $1 / 6$ & & & & & & & \\
\hline C-erbB-2 & & & & & & & & & & & & $0 / 10$ & & & & \\
\hline CD5 & & & & & & & & & & & & & $5 / 7$ & & & \\
\hline CD10 & & & & & & & & & & & & & & & & $4 / 13$ \\
\hline CD15 & & & $2 / 2$ & & & $6 / 12$ & & & & & & & & & & $1 / 13^{\mathrm{a}}$ \\
\hline CD34 & & & & & & & $0 / 5$ & $0 / 6$ & & & & $0 / 10$ & & & & \\
\hline CEA & $2 / 2^{a}$ & $1 / 1^{\mathrm{a}}$ & $2 / 2^{a}$ & $1 / 1^{\mathrm{a}}$ & $1 / 1^{\mathrm{a}}$ & $7 / 12$ & $7 / 7^{\mathrm{a}}$ & & & & $\mathrm{a}$ & & & $\mathrm{a}$ & & $4 / 13^{a}$ \\
\hline CKAE1/AE3 & & & $2 / 2$ & & & $12 / 12$ & $1 / 1$ & & & & $3 / 3$ & $10 / 10$ & & $1 / 1$ & & \\
\hline CK1 & & & & & & & & & & & & & & $1 / 1$ & & \\
\hline CK7 & & & & & & & & & & & & $10 / 10$ & & $\mathrm{a}$ & & $2 / 13^{a}$ \\
\hline CK8 & & & & & & & & & & & & & & $1 / 1$ & & \\
\hline CK13 & & & & & & $8 / 12$ & & & & & & & & & & \\
\hline CK14 & & & & & & $12 / 12$ & & & & & & & & $1 / 1$ & & \\
\hline CK15 & & & & & & & & & & & & & & & & $12 / 13$ \\
\hline CK17 & & & & & & & & & & & & & & $1 / 1$ & & \\
\hline CK19 & & & & & & & & & & & & & & $1 / 1$ & & \\
\hline CK20 & & & & & & & & & & $0 / 8$ & & $0 / 10$ & & $0 / 1$ & & \\
\hline CK903 & & & & & & & & & & & & & & & & $13 / 13$ \\
\hline EMA & & & $2 / 2$ & & & $7 / 12$ & & & & & & $+^{a}$ & & & & \\
\hline ER & & & & & & & & & $2 / 8$ & & & & & & & \\
\hline Ki-67 & & & & & & & & & & & & $<5 \%$ & & & & \\
\hline PCNA & & & & & & & + & & & & & & & & & \\
\hline PR & & & & & & & & & $5 / 8$ & & & & & & & \\
\hline P53 & & & & & & & + & & & & & $2 / 10$ & & & & \\
\hline S100 protein & & $0 / 1$ & $1 / 2$ & & $0 / 1$ & $1 / 12$ & & & & & & $0 / 10$ & & $1 / 1$ & & \\
\hline $\begin{array}{l}\text { Type IV } \\
\text { collagen }\end{array}$ & & & & & & & $0 / 9$ & & & & & & & & & \\
\hline
\end{tabular}

${ }^{\mathrm{a}}$ Luminal staining of ductal structures, filled box: stain was not done. 
Table 2 Comparison of immunohistochemical findings of current study

\begin{tabular}{|c|c|c|c|c|c|c|c|c|c|c|c|c|c|c|c|c|c|c|c|}
\hline \multirow[t]{2}{*}{ Diagnosis (n) } & \multicolumn{3}{|c|}{ CK15 } & \multicolumn{3}{|c|}{$C K 7$} & \multirow{2}{*}{$\begin{array}{c}\text { СК903 } \\
3+\end{array}$} & \multicolumn{3}{|c|}{ CD10 } & \multicolumn{3}{|c|}{$C D 15$} & \multicolumn{2}{|r|}{$C E A$} & \multicolumn{3}{|c|}{ BerEP4 } & \multirow{2}{*}{$\begin{array}{c}\text { CK20 } \\
\text { Neg }\end{array}$} \\
\hline & $3+$ & $2+$ & Neg & $3+$ & $2+$ & $\operatorname{Neg}\left({ }^{a}\right)$ & & $3+$ & $2+$ & $N e g$ & $3+$ & $2+$ & $\operatorname{Neg}\left({ }^{a}\right)$ & $2+$ & $\operatorname{Neg}\left({ }^{\mathrm{a}}\right)$ & $3+$ & $2+$ & $N e g$ & \\
\hline Microcystic adnexal carcinoma (13) & 2 & 10 & 1 & 0 & 2 & $11(1)$ & 13 & 3 & 1 & 9 & 0 & 1 & $12(3)$ & 4 & $9(3)$ & 3 & 2 & 8 & 13 \\
\hline Desmoplastic trichoepithelioma (8) & 6 & 2 & 0 & 0 & 0 & 8 & 8 & 0 & 0 & 8 & 0 & 0 & $7(2)$ & 0 & $8(1)$ & 2 & 2 & 3 & 7 \\
\hline Infiltrative basal cell carcinoma (10) & 0 & 0 & 10 & 3 & 1 & 6 & 10 & 4 & 2 & 4 & 1 & 2 & 7 & 0 & 10 & 10 & 0 & 0 & 10 \\
\hline Squamous cell carcinoma (8) & 0 & 0 & 8 & 0 & 1 & $7(1)$ & 8 & 2 & 0 & 6 & 0 & 0 & $8(2)$ & 0 & $8(5)$ & 1 & 2 & 5 & 8 \\
\hline
\end{tabular}

CK, cytokeratin.

${ }^{\mathrm{a}}$ Luminal staining of ductal structures.
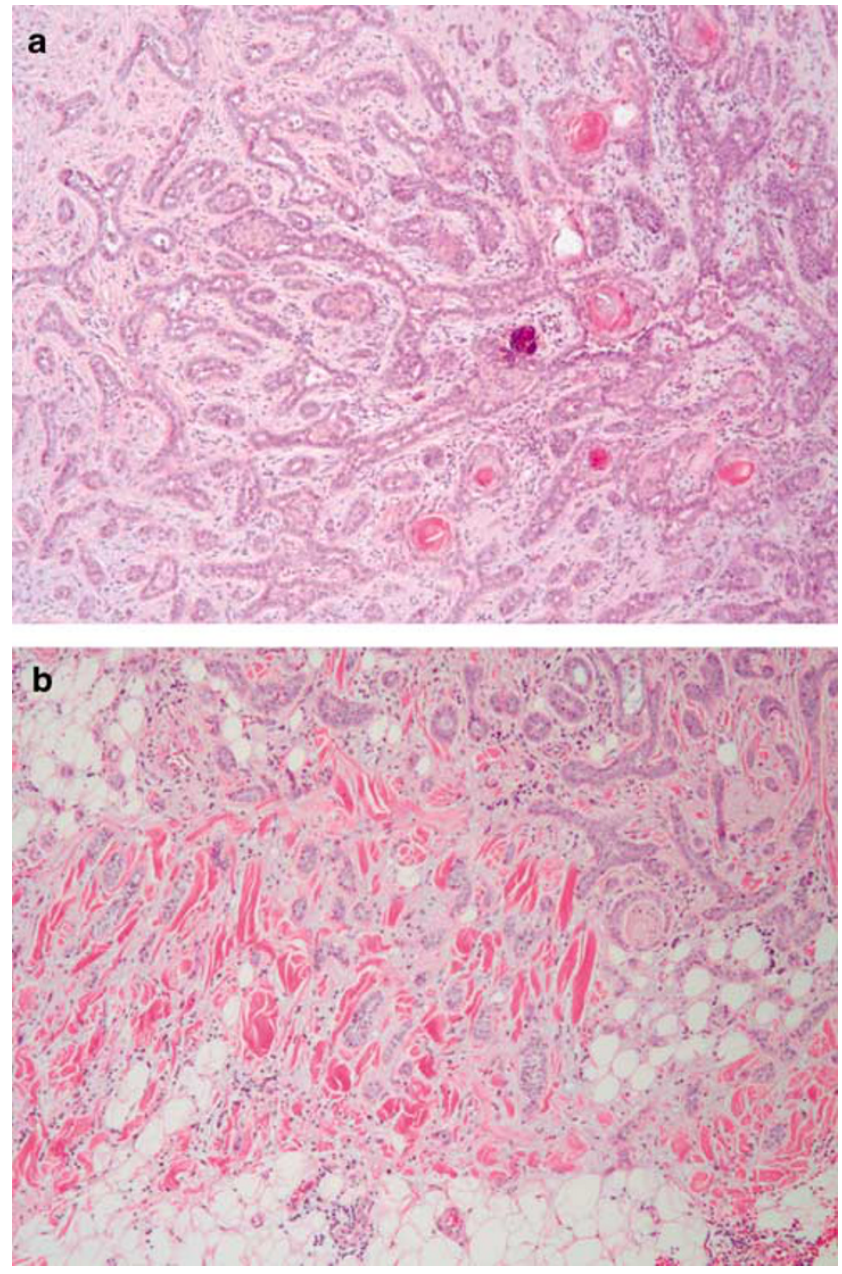

Figure 1 Histologic sections of microcystic adnexal carcinoma show (a) keratocysts, variable ductal differentiation and calcification in the superficial and mid aspect, (b) strands of basaloid cells and perineural invasion in the deep portion of the tumor. Hematoxylin-eosin stain at $\times 10$ magnification.

densely eosinophilic, hyalinized stroma. Perineural invasion was observed (Figure 1b).

Immunohistochemical stains (Table 2) revealed strong positive staining $(3+$, two cases; $2+, 10$ cases) of the lesional cells with CK15 (12 cases, Figure 2c), BerEP4 (five cases) and CK903 (13 cases). Staining for CD10 $(3+)$, CD15 $(2+)$, CK7 $(2+)$ and CEA $(2+)$ was noted in four, one, two and four cases, respectively. Negative staining with CK7 (Figure 2d) was noted in the remaining 11 cases.

\section{Desmoplastic Trichoepithelioma}

A total of eight cases with a male/female ratio of 1:7 were studied (age range, 17-69 years, mean, 39 years; median, 42 years). Involved sites included the nose (three patients), cheek (two patients), lip, shoulder and chest.

Histologic features of all cases were characterized by a well-circumscribed tumor in the superficial and mid dermis that contained keratinous cysts, cords and nests of basaloid cells within a fibrous stroma, and occasional foci of dystrophic calcification (Figure 2e and f).

Immunohistochemical stains (Table 2) revealed positive staining $(3+$, six cases; $2+$, two cases) of the lesional cells with CK15 (eight cases, Figure 2g), BerEP4 (four cases) and CK903 (eight cases). Negative staining with CK7 (Figure 2h), CD10, CD15 and CEA was noted in all eight cases.

\section{Infiltrating Basal Cell Carcinoma}

A total of 10 cases with a male/female ratio of $6: 4$ were studied (age range, 40-85 years, mean, 69 years; median, 70 years). Involved sites included the nose (two patients), forehead (two patients), temple, preauricular, back (two patients), chest and lower leg.

Histologic sections of all cases showed elongate strands of basaloid cells infiltrating between the collagen bundles (Figure 2i and j).

Immunohistochemical stains (Table 2) revealed positive $(3+$, three cases; $2+$, one case) staining of the lesional cells with CK7 (four cases, Figure 2l), BerEP4 (10 cases), CK903 (10 cases), CD10 (six cases), and CD15 (three cases). Negative staining with CK15 (Figure 2k) and CEA was noted in all 10 cases.

\section{Squamous Cell Carcinoma}

A total of eight cases with a male/female ratio of 5:3 were studied (ages range, 57-90 years, mean, 67 years; median, 64 years). Involved sites include 


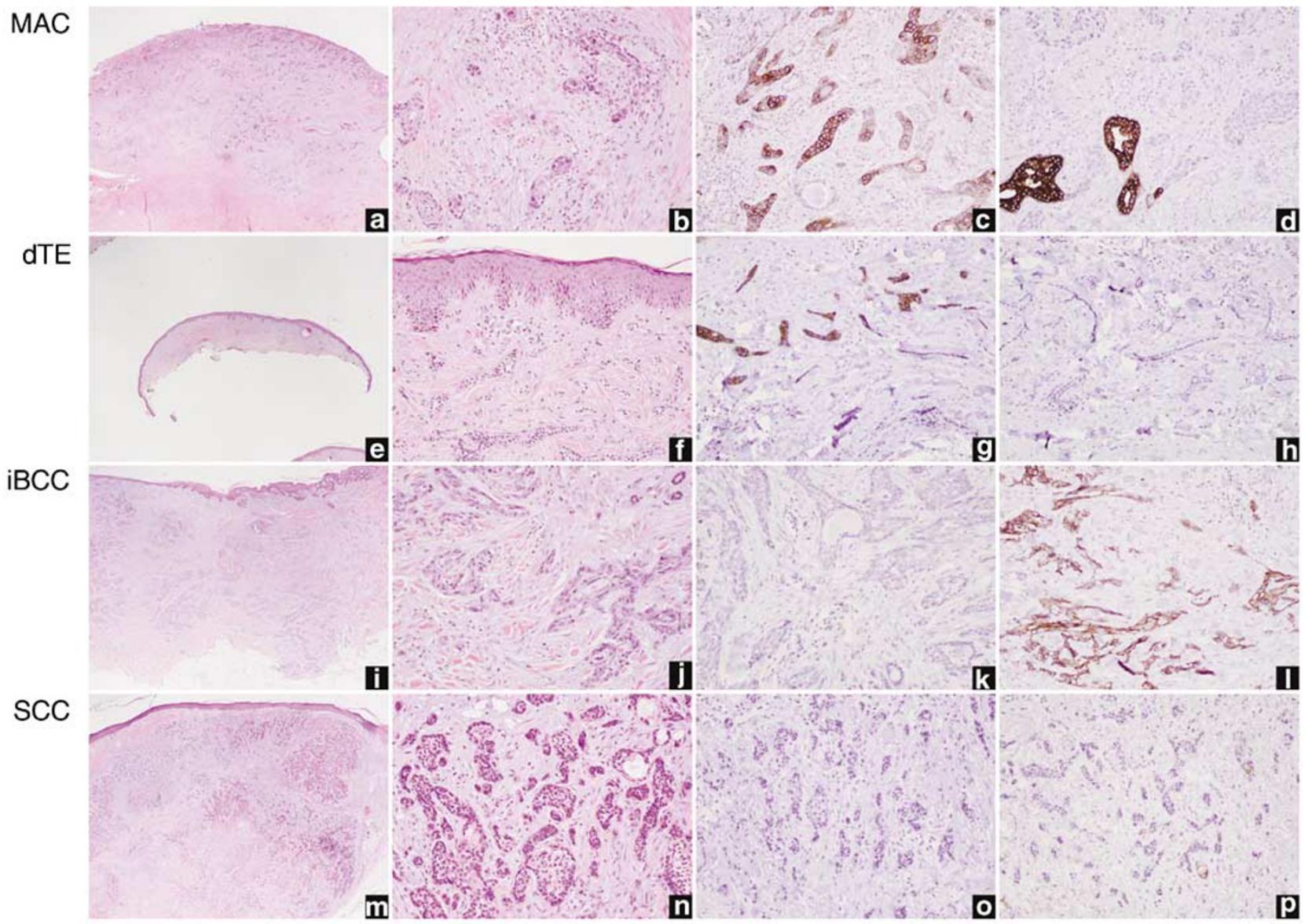

Figure 2 CK15 and CK7 expression in microcystic adnexal carcinoma (MAC (a-d)), desmoplastic trichoepithelioma (dTE (e-h)), infiltrative basal cell carcinoma (iBCC (i-l)), and squamous cell carcinoma (SCC $(\mathbf{m}-\mathbf{p})$ ). Hematoxylin-eosin stain at $\times 20$ and $\times 200$ magnification. CK15 and CK7 immunoperoxidase at $\times 200$ magnification.

scalp, forehead, nose, cheek, arm (two cases), hand, and back.

Histologic sections of five cases of squamous cell carcinoma with ductal differentiation showed a poorly circumscribed, infiltrative tumor with prominent squamous differentiation and extensive foci of ductal differentiation (Figure $2 \mathrm{~m}$ and $\mathrm{n}$ ).

Immunohistochemical stains (Table 2) revealed positive $(3+)$ staining of the lesional cells with CK903 (eight cases), BerEP4 (three cases) and CD10 (two cases). With the exception of $2+$ CK7 staining in one case, negative staining with CK15 (Figure 2o), CK7 (Figure 2p), CD15 and CEA was noted in all cases.

\section{Discussion}

Microscopically, microcystic adnexal carcinoma is typically stratified and characterized by a superficial component of keratinous cysts and a deeper component of smaller nests and strands of cells embedded in a markedly hyalinized stroma-features that will not be apparent in a superficial shave biopsy specimen. In the published literature, misdiagnosis of microcystic adnexal carcinoma as desmoplastic trichoepithelioma, morpheaform basal cell carcinoma, eccrine carcinoma with squamous differentiation or even squamous cell carcinoma has been reported in anywhere from $30-52 \%$ of cases. ${ }^{6,18}$ The utility of immunohistochemistry as a histologic adjunct is particularly important given that the distinction between these neoplasms is not just semantics, but crucial to directing appropriate patient management. As microcystic adnexal carcinoma tend to be locally infiltrating and have a propensity for perineural invasion, wide surgical excision (with a view to achieving wide negative margins with or without Mohs technique) is the treatment of choice.

Published literature to date indicates that no marker diagnostic for microcystic adnexal carcinoma exists. A novel immunohistochemical stain included in the current study, and one whose expression has not been previously documented in microcystic adnexal carcinoma, is CK15. ${ }^{27}$ CK15, labeling a population of cells in the hair follicle bulge with properties of adult epithelial stem cells, 
has been found to be expressed in fetal and adult sebaceous glands and a variety of both benign (sebaceous adenoma, basaloid follicular hamartoma, inverted follicular keratosis, proliferating trichilemmal tumor, trichilemmal cyst, and dilated pore of Winer) and malignant neoplasms (sebaceous carcinoma, trichoblastic carcinoma). ${ }^{27-29}$ On the basis of its expression in only tumors with follicular differentiation, CK15 is believed by some to be a relatively specific marker for hair follicle-related neoplasms. ${ }^{27}$ In keeping with this hypothesis, CK15 expression has been reported in basal cell carcinoma (only the nodular and keratotic subtypes) and desmoplastic trichoepithelioma with, understandably enough, negative expression in squamous cell carcinoma. ${ }^{27}$ We found the majority of cases of microcystic adnexal carcinoma (92\%) in our study to be CK15 positive. As noted previously, we found absence of CK15 expression in cases of infiltrative basal cell carcinoma and squamous cell carcinoma. Thus, CK15 appears to be a useful marker in distinguishing microcystic adnexal carcinoma from squamous cell carcinoma and infiltrative basal cell carcinoma. However, we also noted that all of the desmoplastic trichoepithelioma cases were also CK15 positive arguing against the specificity of CK15. It is noteworthy that, strong expression $(3+)$ of CK15 was observed in $75 \%$ of cases of desmoplastic trichoepithelioma compared to $15 \%$ of cases of microcystic adnexal carcinoma (see Table 2).

Our findings regarding expression of CK7 in microcystic adnexal carcinoma and desmoplastic trichoepithelioma conflict those by Smith et al. ${ }^{23}$ Briefly, they found all of their cases of microcystic adnexal carcinoma to exhibit CK7 positivity, while all their cases of infiltrative basal cell carcinoma were negative. ${ }^{23}$ In our study by contrast, $16 \%(2 / 12)$ of microcystic adnexal carcinoma cases and $40 \%$ (4/10) infiltrative basal cell carcinoma expressed CK7. This discrepancy may be a function of different staining methods and employed antibody dilution since the same clone of antibody used to identify CK7 in the two studies. Our experience with expression of CK7 in desmoplastic trichoepithelioma is however similar to that of Smith et $a l^{23}$ in that, all cases were CK7 negative. In keeping with our findings, Yamamoto et $a l^{30}$ found that basal cell carcinoma (nodular and keratotic variants) but not trichoepithelioma expressed CK7. Thus, from a practical perspective it appears that a combination of CK15 and CK7 would be very helpful in distinguishing microcystic adnexal carcinoma from infiltrative basal cell carcinoma and squamous cell carcinoma. Using these two antibodies, the immunohistochemical profile of microcystic adnexal carcinoma would be either CK15 + CK7 - or CK15 +/CK7 + while infiltrative basal cell carcinoma would be CK15-CK7 + and squamous cell carcinoma would be CK15-CK7-. Expression of CK7 in undifferentiated epithelium, in addition to secretory epithelium, in early development may perhaps explain our observation of CK7 luminal staining of some of the ductal structures in microcystic adnexal carcinoma. $^{31}$

To date, conflicting reports exist regarding expression of CK20, a marker used to denote presence of Merkel cells, in microcystic adnexal carcinoma vs desmoplastic trichoepithelioma. ${ }^{21,23}$ While, Abesamis-Cubillan et al $^{21}$ observed Merkel cells in all 14 cases of desmoplastic trichoepithelioma, but in none of the eight microcystic adnexal carcinoma cases, in the study by Smith et $a l^{23}$ Merkel cells were not seen in either. In keeping with the experience of the latter, we found negative staining with CK20 in the majority of cases of desmoplastic trichoepithelioma (7/8) and all microcystic adnexal carcinoma cases. Thus, while the precise utility of CK20 is yet to be ascertained, our experience indicates that it is not useful in separating microcystic adnexal carcinoma from desmoplastic trichoepithelioma.

Only three cases of microcystic adnexal carcinoma $(30 \%)$ in our study expressed CD10, arguing against its utility as an immunohistochemical adjunct. The strong expression of CD10 in the majority of our cases of infiltrative basal cell carcinoma $(60 \%)$ is in keeping with previous reports indicating strong expression of CD10 in up to $86-87 \%$ of basal cell carcinoma. ${ }^{32,33}$ Interestingly enough, while CD10 reportedly only stains the stromal cells in squamous cell carcinoma, we noted CD10 expression in the lesional cells in two cases $(25 \%))^{32}$

A more recent study by Krahl et $a l^{26}$ indicates absence of BerEP4, a monoclonal antibody recognizing two glycopolypeptides ( 34 and $39 \mathrm{kDa}$ ) found in most human epithelial cells, in all c(13/13) cases of microcystic adnexal carcinoma, and presence in all (28/28) cases of infiltrative basal cell carcinoma, thus attesting to its utility in separating microcystic adnexal carcinoma from infiltrative basal cell carcinoma. ${ }^{34}$ The utility of this antibody in distinguishing basal cell carcinoma and squamous cell carcinoma based upon its consistent expression in the former and absence in the latter is well documented. ${ }^{35,36}$ While we also found BerEP4 in all cases of infiltrative basal cell carcinoma in our study, we noted strong BerEP4 expression in 38\% our microcystic adnexal carcinoma cases. Similar to our study, Smith et $a l^{23}$ reported BerEP4 immunoreactivity in glandular areas of their 10 cases of microcystic adnexal carcinoma. Thus, BerEP4 does not appear to be helpful in distinguishing microcystic adnexal carcinoma from infiltrative basal cell carcinoma. It also does not appear to distinguish microcystic adnexal carcinoma from desmoplastic trichoepithelioma as our experience, similar to that of Krahl et $a l^{26}(75 \%)$ and Swanson et $a l^{37}(71 \%)$, indicates that up to $57 \%$ of desmoplastic trichoepithelioma are positive for BerEP4.

On the basis of the expression of carcinoembryonic antigen, epithelial membrane antigen, and cytokeratin, published studies have argued for pilar, 
eccrine, apocrine, or even sebaceous differentiation in microcystic adnexal carcinoma even though subsequent studies have shown that these markers are not specific. ${ }^{12,14,17,38-41}$ In our study, while expression of CK15 in the majority of cases of microcystic adnexal carcinoma argues in favor of pilar differentiation, luminal ductal staining with CK7, CD15 and CEA is suggestive of sweat gland differentiation. Ultrastructural studies confirm this dual pilar and sweat gland differentiation. ${ }^{13,16}$ Thus, it is likely that microcystic adnexal carcinoma exhibits both pilar and apocrine differentiation since these are indeed embryologically related..$^{18}$ The hair follicles develop two or three bulges on their undersurface in the early bulbous stage. ${ }^{42}$ The uppermost bulge, if present, either involutes or develops into an apocrine gland. ${ }^{42}$ The remaining two lower bulges develop into pilar muscle attachment and sebaceous gland, respectively ${ }^{42}$ The latter would explain the sebaceous differentiation that is rarely noted in microcystic adnexal carcinoma. ${ }^{40,41}$

In conclusion, we found that CK15 is a useful marker in distinguishing microcystic adnexal carcinoma from infiltrative basal cell carcinoma and squamous cell carcinoma with ductal differentiation. In addition, a panel of CK15 and CK7 increases the diagnostic specificity. In our study, microcystic adnexal carcinoma and desmoplastic trichoepithelioma had the same immunoprofile that is CK15 + and BerEP4 $+/-$. Thus, while our results narrow the differential diagnosis of an infiltrating basaloid proliferation, it is apparent that, for now at least, the quest for an immunohistochemical marker specific to microcystic adnexal carcinoma is not complete.

\section{References}

1 Goldstein DJ, Barr RJ, Santa Cruz DJ. Microcystic adnexal carcinoma. A distinct clinicopathologic entity. Cancer 1982;50:566-572.

2 Lipper S, Peiper SC. Sweat gland carcinoma with syringomatous features: a light microscopic and ultrastructural study. Cancer 1979;44:157-163.

3 Glatt HJ, Proia AD, Tsoy EA, et al. Malignant syringoma of the eyelid. Ophthalmology 1984;91: 987-990.

4 Cooper PH, Mills SE, Leonard D, et al. Sclerosing sweat duct (syringomatous) carcinoma. Am J Surg Pathol 1985;9:422-433.

5 Alessi E, Caputo R. Syringomatous carcinoma of the scalp presenting as a slowly enlarging patch of alopecia. Am J Dermatopathol 1993;15:503-505.

6 Chiller K, Passaro D, Scheuller M, et al. Microcystic adnexal carcinoma. Forty-eight cases, their treatment, and their outcome. Arch Dermatol 2000;136: 1355-1359.

7 Friedman PM, Friedman RH, Jiang SB, et al. Microcystic adnexal carcinoma: collaborative series review and update. J Am Acad Dermatol 1999;41:225-231.

8 Santa Cruz DJ. Sweat gland carcinomas: a comprehensive review. Semin Diagn Pathol 1987;4:38-74.
9 Cooper PH. Sclerosing carcinomas of sweat ducts (microcystic adnexal carcinoma). Arch Dermatol 1986; 122:261-264.

10 Sebastien TS, Nelson BR, Lowe L, et al. Microcystic adnexal carcinoma. J Am Acad Dermatol 1993;29: 840-845.

11 Lupton GP, McMarlin SL. Microcystic adnexal carcinoma: report of a case with a 30-year follow-up. Arch Dermatol 1986;122:286-289.

12 Nickoloff BJ, Fleischmann HE, Carmel J, et al. Microcystic adnexal carcinoma: immunohistochemical observations suggesting dual (pilar and eccrine) differentiation. Arch Dermatol 1986;122:290-294.

13 Kato H, Mizuno N, Nakagawa K, et al. Microcystic adnexal carcinoma: a light microscopic, immunohistochemical and ultrastructural study. J Cutan Pathol 1990;17:87-95.

14 Swanson PE, Cherwitz DL, Newmann MP, et al. Eccrine sweat gland carcinoma: a histiologic and immunohistochemical study of 32 cases. J Cutan Pathol 1987;14:65-86.

15 Ceballos PI, Penneys NS, Cohen BH. Microcystic adnexal carcinoma: a case showing eccrine duct differentiation. J Dermatol Surg Oncol 1988;14: 1236-1239.

16 Miyamoto T, Kambe N, Nishiura S, et al. Microcystic adnexal carcinoma: electron microscopic and immunohistochemical study. Dermatologica 1990;180: 40-43.

17 Wick MR, Cooper PH, Swanson PE, et al. Microcystic adnexal carcinoma. An immunohistochemical comparison with other cutaneous appendage tumors. Arch Dermatol 1990;126:189-194.

18 LeBoit PE, Sexton M. Microcystic adnexal carcinoma of the skin. A reappraisal of the differentiation and differential diagnosis of an under-recognized neoplasm. J Am Acad Dermatol 1993;29:609-618.

19 Kirchmann TT, Prieto VG, Smoller BR. Use of CD34 in assessing the relationship between stroma and tumor in desmoplastic keratinocytic neoplasms. J Cutan Pathol 1995;22:422-426.

20 Wallace ML, Longacre TA, Smoller BR. Estrogen and progesterone receptors and anti-gross cystic disease fluid protein 15 (BRST-2) fail to distinguish metastatic breast carcinoma from eccrine neoplasms. Mod Pathol 1995;8:897-901.

21 Abesamis-Cubillan E, El-Shabrawi-Caelen L, LeBoit PE. Merkel cells and sclerosing epithelial neoplasms. Am J Dermatopathol 2000;22:311-315.

22 Urso C, Bondi R, Paglierani M, et al. Carcinomas of sweat glands: report of 60 cases. Arch Pathol Lab Med 2001;125:498-505.

23 Smith KJ, Williams J, Corbett D, et al. Microcystic adnexal carcinoma: an immunohistochemical study including markers of proliferation and apoptosis. Am J Surg Pathol 2001;25:464-471.

24 Bogner PN, Su LD, Fullen DR. Cluster designation 5 staining of normal and non-lymphoid neoplastic skin. J Cutan Pathol 2005;32:50-54.

25 Nagatsuka H, Rivera RS, Gunduz M, et al. Microcystic adnexal carcinoma with mandibular bone marrow involvement. A case report with immunohistochemistry. Am J Dermatopathol 2006;28:518-522.

26 Krahl D, Sellheyer K. Monoclonal antibody Ber-EP4 reliably discriminates between microcystic adnexal carcinoma and basal cell carcinoma. J Cutan Pathol 2007;34:782-787. 
27 Jih DM, Lyle S, Elenitsas R, et al. Cytokeratin 15 expression in trichoepitheliomas and a subset of basal cell carcinomas suggests they originate from hair follicle stem cells. J Cutan Pathol 1999;26:113-118.

28 Lyle S, Christofidou-Solomidou M, Liu Y, et al. The C8/144B monoclonal antibody recognizes cytokeratin 15 and defines the location of human follicle stem cells. J Cell Sci 1998;111:3179-3188.

29 Bieniek R, Lazar AJF, Photopoulos C, et al. Sebaceous tumors contain a subpopulation of cells expressing the keratin 15 stem cell marker. Br J Dermatol 2007;156: 378-380.

30 Yamamoto O, Asahi M. Cytokeratin expression in trichoblastic fibroma (small nodular type trichoblasto$\mathrm{ma}$ ), trichoepithelioma and basal cell carcinoma. Br J Dermatol 1999;140:8-16.

31 Li C, Okamoto Y, Ohmura H, et al. Expresssion of cytokeratins in Warthin's tumor (adenolymphoma) of parotid glands: specific detection of individual cytokeratin types by monoclonal antibodies. Eur J Cancer B Oral Oncol 1996;32B:352-358.

32 Yada K, Kashima K, Daa T, et al. Expression of CD10 in basal cell carcinoma. Am J Dermatopathol 2004;26:463-471.

33 Pham TT, Selim MA, Burchette Jr JL, et al. CD10 expression in trichoepithelioma and basal cell carcinoma. J Cutan Pathol 2006;33:123-128.

34 Latza U, Neidobitek G, Schwarting R, et al. Ber-EP4: new monoclonal antibody, which distinguishes epithelia from mesothelial. J Clin Pathol 1990;43:213-219.
35 Beer TW, Shepherd P, Theaker JM. Ber EP4 and epithelial membrane antigen aid distinction of basal cell, squamous cell and basosquamous carcinomas of the skin. Histopathol 2000;37:218-223.

36 Tellechea O, Reis JP, Domingues JC, et al. Monoclonal antibody Ber EP4 distinguishes basal cell carcinoma from squamous cell carcinoma of the skin. Am J Dermatopathol 1993;15:452-455.

37 Swanson PE, Fitzpatrick MM, Ritter JH, et al. Immunohistologic differential diagnosis of basal cell carcinoma, squamous cell carcinoma, and trichoepithelioma in small biopsy specimens. J Cutan Pathol 1998;25:153-159.

38 Zuk JA, West KP, Fletcher A. Immunohistochemical staining patterns of sweat glands and their neoplasms using two monoclonal antibodies to keratins. J Cutan Pathol 1988;15:8-17.

39 Requena L, Kiryu H, Ackerman AB. Neoplasms with Apocrine Differentiation. Lippincott-Raven and Ardor Scribendi: Philadelphia, 1997.

40 Pujol RM, LeBoit PE, Su WP. Microcystic adnexal carcinoma with extensive sebaceous differentiation. Am J Dermatopathol 1997;19:358-362.

41 Heenan PJ. Sebaceous differentiation in microcystic adnexal carcinoma. Am J Dermatopathol 1998;20: 537-538.

42 Hashimoto K. The ultrastructure of the skin of human embryos. VII. Formation of the apocrine gland. Acta Derm Venereol 1970;50:241-251. 